\title{
Stacking of Pup1 QTL for Low Soil Phosphorus Tolerance and Bacterial Blight Resistance Genes in the Background of APMS6B, the Maintainer Line of Rice Hybrid DRRH-3
}

\author{
Madhusudan N \\ Indian Institute of Rice Research \\ Beulah P \\ Indian Institute of Rice Research \\ VEERENDRA JALDHANI \\ Indian Institute of Rice Research \\ Nagaraju P \\ Indian Institute of Rice Research \\ Manasa $Y$ \\ Indian Institute of Rice Research
}

\section{Sundaram RM}

Indian Institute of Rice Research

Laha GS

Indian Institute of Rice Research

HariPrasad AS

Indian Institute of Rice Research

Anantha MS

Indian Institute of Rice Research

Kemparaju KB

Indian Institute of Rice Research

Gireesh C

Indian Institute of Rice Research

Gobinath R

Indian Institute of Rice Research

Kalyani M Barbadikar

Indian Institute of Rice Research

Brajendra P

Indian Institute of Rice Research

Tuti MD

Indian Institute of Rice Research 
Mahender Kumar R

Indian Institute of Rice Research

SENGUTTUVEL P ( $\square$ senguttuvel@gmail.com )

ICAR-Indian Institute of Rice Research https://orcid.org/0000-0002-2811-7046

\section{Research Article}

Keywords: Rice, Low phosphorus tolerance, Bacterial Blight, maintainer line, APMS6B, MABB, hybrids.

Posted Date: September 30th, 2021

DOl: https://doi.org/10.21203/rs.3.rs-883401/v1

License: (c) (1) This work is licensed under a Creative Commons Attribution 4.0 International License. Read Full License 
1 Full Title: Stacking of Pupl QTL for low soil phosphorus tolerance and bacterial blight resistance genes in the

2 background of APMS6B, the maintainer line of rice hybrid DRRH-3

3

4 Author Names: Madhusudan N, Beulah P, Jaldhani V, Nagaraju P, Manasa Y, Sundaram RM, Laha GS, HariPrasad

5 AS, Anantha MS, Kemparaju KB, Gireesh C, Gobinath R, Kalyani M Barbadikar, Brajendra P, Tuti MD, Mahender

6 Kumar R, Senguttuvel P*

7

8 Corresponding author: Dr. P. Senguttuvel (email: senguttuvel@gmail.com) Crop Improvement Section, ICAR-

9 Indian Institute of Rice Research, Hyderabad, India +91 40 24591297; Fax: +91 4024591217

10

11 Author affiliation: Crop Improvement Section, ICAR-Indian Institute of Rice Research, Hyderabad, India

12

13 Acknowledgement: Authors are grateful to Indian Council of Agriculture Research (ICAR), ICAR-Indian Institute

14 of Rice Research (ICAR-IIRR) and Govt. of India for their financial support and facilities for research. 
Stacking of Pup1 QTL for low soil phosphorus tolerance and bacterial blight resistance genes in the background of APMS6B, the maintainer line of rice hybrid DRRH-3 Abstract

Phosphorus $(\mathrm{P})$ is one of the macro nutrients essential for plant growth and development. Rice (Oryza sativa L.) is sensitive to $\mathrm{P}$ starvation and its deficiency influences many key plant functions which results in crop yield penalty. Although the hybrid rice segment is well-known for its yield heterosis, P deficiency and bacterial leaf blight (BLB) diseases are the evident limitations. APMS6B, the female parent of DRRH-3 is susceptible to low P and bacterial blight disease. In the present study, the improvement of APMS6B to P starvation and resistance to bacterial leaf blight (BB) was carried out using marker-assisted backcross breeding (MABB) approach. Kasalath (+ Pupl QTL) was used as donor and a promising IL (ATR 594-1) at $\mathrm{BC}_{1} \mathrm{~F}_{4}$ generation was identified with $81.15 \%$ RPGR. Concurrently, this IL was intercrossed with GU-2 (+ Xa21 and Xa38). Hybridity of Intercross $\mathrm{F}_{1} \mathrm{~s}\left(\mathrm{ICF}_{1}\right)$ was confirmed through foreground selection having maximum RPGR $(88.29 \%)$ and were selfed to produce $\mathrm{ICF}_{2}$. The resultant progenies were phenotyped for BB using Xoo inoculum (IX-020), simultaneously genotyped with gene specific functional SSR markers for Xa21 and Xa38. The identified BB resistant plants were subjected to foreground selection for Pup1. Four promising $\mathrm{ICF}_{3}$ plants (BP-10-1, BP-10-3, BP-10-5 and BP-10-15 with Xa21, Xa38 and Pup1) along with parents and checks were screened both in low $\mathrm{P}$ plot $\left(<2 \mathrm{~kg} \mathrm{P}_{2} \mathrm{O}_{5} \mathrm{ha}^{-1}\right)$ as well as in normal plot (>25 $\mathrm{kg} \mathrm{P}_{2} \mathrm{O}_{5} \mathrm{ha}^{-1}$ ) during dry and wet seasons 2018. Based on the field evaluation, four promising intercrossed lines were identified with better root architecture in terms of root length and root volume. In addition, less \% reduction in grain yield $(39.10 \%)$ under P starvation and less susceptibility indices values $(<1)$ for BB were observed. These lines may be utilized in the CMS conversion programme and development of climate resilient, biotic and abiotic tolerant rice hybrids.

Key words: Rice, Low phosphorus tolerance, Bacterial Blight, maintainer line, APMS6B, MABB, hybrids. 


\section{INTRODUCTION}

Rice is a major staple food crop for more than half of the world population and sole livelihood in Asian and African countries. Over the last few years, the yield potential of popular high yielding semi-dwarf rice varieties has encountered yield stagnation and further constrained by various biotic and abiotic stresses. Phosphorus deficiency is one of the least addressed and major yield limiting macro-nutrients in rice that steer to greater yield loss (Fageria and Baligar 1997; Rose et al. 2013). Globally, majority of soils (>50\%) are P deficit and similarly Indian soils are either P deficient (49.3\%) or medium level insufficiency (48.8\%) or else possesses high P-fixing capacity and only $1.9 \%$ of soils are high in available P (Hasan 1996). Increased fertilizer costs and gradual depletion of rock phosphate, forced the country as the largest importer (90\%) of P fertilizer (WEBECK et al. 2014). With increase in human population, reduction in arable lands and limited availability of fertilizer resources, sustainable rice production for diverse rice ecologies are major issues need to be addressed. There is an immense need to develop rice varieties and hybrids with enhanced $P$ uptake efficiency to address $P$ starvation tolerance (Heuer et al. 2017). To overcome the $\mathrm{P}$ crisis, various agronomic and soil amelioration strategies are in force, however, sustainable, ecofriendly and long term approaches of breeding genotypes for low $\mathrm{P}$ is need of the hour. Genetic studies and screening of rice germplasm for $\mathrm{P}$ use efficiency and tolerance to low soil $\mathrm{P}$ is well documented (Fageria et al. 1988a; Fageria et al. 1988b; Wissuwa et al. 1998; Chin et al. 2011). A major QTL, Pup1 associated with tolerance to low available soil $\mathrm{P}$ has been identified on chromosome 12 in an indica aus type landrace, Kasalath and was very well characterized (Wissuwa et al. 1998; Wissuwa et al. 2002; Heuer et al. 2009). The QTL Pupl has been finemapped and closely linked markers have been developed (Chin et al. 2009). A protein kinase gene OsPSTOL1 was identified within Pup1 QTL region, which promotes extensive root growth, enabling enhanced uptake of P from the soil. Many of the modern rice cultivars lack Pupl loci and thereby are susceptible to P starvation. Successful attempts were made to introgress OSPSTOL1 through marker-assisted breeding into the elite rice varieties like IR64, ASD 16, ADT 43, BPT 5204, Improved Samba Mahsuri (Swamy et al. 2020; Anila et al. 2018; Chin et al. 2011; Chithrameenal et al. 2018). Phenotypic evaluation of the introgression lines infers that Pupl is effective in different genetic backgrounds and has the potential to significantly enhance grain yield under irrigated and rainfed ecosystems of rice cultivation having low soil phosphorus (Chin et al. 2011). Among the biotic stresses, bacterial blight (BB) is a serious disease of rice at maximum tillering stage and consequent yield loss of up to 80\% (Mew 1987; Mew 1993). Chemical control being ineffective and environmentally hazardous, the development and introduction of resistant cultivars is the most economical, effective and eco-friendly method of controlling bacterial blight disease (Khush GS, Mackill DJ 1989; Ogawa 1993). Presently 46 bacterial blight resistance genes have been identified (Zhou et al. 2011; Kim et al. 2015) and available for genetic improvement of rice cultivar for bacterial blight disease. Pyramiding two or more BB resistant genes into a single rice variety helps to develop durable BB resistance rice varieties (Khush GS, Mackill DJ 1989).

71 Hybrid rice is a promising technology with exploitation of standard heterosis for yield and responds well to high

72 inputs like chemical fertilizers. Three-line hybrid rice breeding programme in India have been successful by utilizing an elite wild-abortive (WA) cytoplasm (Senguttuvel et al. 2019) and till-date, 127 rice hybrids are released 
slender rice hybrid released for commercial cultivation in 2008 by ICAR-Indian Institute of Rice Research (ICARIIRR) (https://www.icar-iirr.org/). However, DRRH-3 encounters both abiotic and biotic stresses; especially bacterial blight and P deficiency which are of prime importance in India. Neither the CMS line (APMS6B) and the restorer line (RPHR 1005) nor does the derived hybrid (DRRH-3) acquire tolerance to low phosphorus and resistance to BB. In previous study, the improved maintainer line APMS6B of DRRH-3 known as GU-2, was developed by incorporating two bacterial leaf blight (BB) resistance genes (Xa21 and Xa38), through marker assisted backcross breeding (MABB) approach (Yugander et al. 2018). The scope of marker-assisted breeding for targeted introgression of BB resistance genes (Yugander et al. 2018; Sundaram et al. 2008; Amante-Bordeos et al. 1992; Hittalmani et al. 2000) and Pupl (Swamy et al. 2020; Anila et al. 2018; Chin et al. 2011; Chithrameenal et al. 2018) has been successfully demonstrated. In all these studies, either BB resistance or low P tolerant genes (any two traits) were introgressed separately into commercial varieties. In the present study, we have attempted to stack Pup-1 from Kasalath and BB resistant genes from improved APMS6B line GU-2 using marker-assisted backcross breeding strategy coupled with phenotype-based selection. To the best of our knowledge, this is the first report on improvement of low $\mathrm{P}$ tolerance combined with bacterial leaf blight in hybrid rice maintainer line.

\section{Materials and methods}

\section{Plant materials: Recurrent Parent - APMS6B}

APMS6B, an elite, sturdy with medium slender (MS) grain maintainer line of DRRH-3 hybrid, was used as recurrent parent. The maintainer line has good combining ability and dwarf plant stature but is highly susceptible to $\mathrm{BB}$ and intolerant to low phosphorus soil.

\section{Donor for Pup1: Kasalath}

95 Kasalath, an Indian aus type land race adapted to poor soils contains beneficial allele for drought tolerance, phosphate-deficiency tolerance and early maturity (Gamuyao et al. 2012) was used as Pupl donor.

\section{Donor for Bacterial Blight}

98 GU-2 is a Near Isogenic Line of APMS6B, developed through marker assisted backcross breeding of two bacterial blight resistance genes viz., Xa21 and Xa38 to confer broad spectrum resistance to bacterial blight (Yugander et al. 2018) and has medium slender grain and excellent cooking quality which was used as donor parent for bacterial leaf blight disease. The parental lines viz., APMS6B, GU-2, RPHR 1005 (male parent of DRRH-3) and hybrid DRRH-3 were intolerant to low soil $P$.

\section{DNA markers for Pup1 and BB and genotyping}

104 DNA isolation from the parents, $\mathrm{F}_{1} \mathrm{~s}$, and intercross-derived plants was carried out using a Miniprep protocol (Zheng KL. 1995). PCR protocol described by Chin et al. (2011) was adopted for the markers associated with Pup-1 (K461, 46-2) and BB gene Xa21 specific marker, pTA248 and Xa38 specific marker, Os04g5350-1 was followed as suggested by Ronald et al. (1992) and (Bhasin et al. 2012) respectively (Table-1). While for the amplification of rice SSR markers, the protocol described in Sundaram et al. (2008) was followed. The amplified products of K46-1, K46-2, pTA248 (Xa21) and Os04g5350-1 (Xa38) were electrophoretically resolved in 2\% and 1.2\% Seakem LE agarose gel (Lonza, USA), while the amplified fragments from SSR markers were resolved on 3.5\% agarose gels. 

( $\mathrm{n}=111)$ which were distributed evenly covering all the 12 chromosomes were used for background selection and to identify those positive plants, which have maximum recovery of the recurrent parent genome as described in Sundaram et al. (2008).

\section{Breeding strategy for Marker-assisted transfer of Pup1 and Xa21 \& Xa38}

117 The detailed scheme of hybridization programme is shown in Figure-1. The maintainer line APMS6B was crossed with Kasalath. The true $\mathrm{F}_{1} \mathrm{~s}$ were confirmed with K46-1 marker and backcrossed with APMS6B. The resultant $\mathrm{BC}_{1} \mathrm{~F}_{1}$ was further confirmed for hybridity with K46-1. Based on background selection, one line with maximum recovery of parental genome was selfed to produce $\mathrm{BC}_{1} \mathrm{~F}_{2}$. These lines were screened under low $\mathrm{P}$ soil in field condition. Based on superior performance for agro morphological traits for low P, the line ATR 594-1, an introgression line of APMS6B and Kasalath was identified as improved donor for Pup1. Further, GU-2 (a donor for $\mathrm{Xa21}$ and $\mathrm{Xa38}$ ) was crossed with ATR-594-1. At the time of initiation of the present work, GU-2 lines were not stabilized to use directly as donor with Kasalath. The true inter cross $F_{1} s$ were identified with the help of the functional dominant markers, K46-1 and K46-2 (Chin et al. 2011). True intercross $F_{1}$ with maximum recovery of recurrent parent genome was selfed to get intercross $\mathrm{F}_{2} . \mathrm{ICF}_{2}$ plants were screened for bacterial blight resistance with inoculum of IXI020 available at ICAR-IIRR Hyderabad (Laha et al. 2009). Plants showing phenotypic resistance to BB and agronomic desirable plant type were screened for foreground selection for Pup-1 and Xa21, Xa38. Plants showing positive for Pup1, Xa21 and Xa38 were selfed to get intercross $\mathrm{F}_{3}$. Parental lines (APMS6B, GU-2, RPHR 1005 and DRRH3) and four $\mathrm{ICF}_{3}$ selected lines were sown in normal soil. Thirty days old seedlings were then transplanted in low soil $\mathrm{P}$ (low soil phosphorus $<2 \mathrm{~kg} \mathrm{P}_{2} \mathrm{O}_{5} \mathrm{ha}^{-1}$ ) plot of ICARIIRR, Hyderabad, Telangana state, India (Latitude $17.3201^{\circ} \mathrm{N}$, Longitude $78.3939^{\circ} \mathrm{E}$ and $542 \mathrm{~m}$ above MSL), at a spacing of $15 \times 20 \mathrm{~cm}$ (in three rows, 10 hills per row) along with the donor and recurrent parents and grown until maturity. The plants were also grown in graded plots with normal soil P (>25 $\mathrm{kg} \mathrm{P}_{2} \mathrm{O}_{5}$ ha $^{-1}$ ) in three rows with 20 hills per row for comparison of performance. Standard agronomic practices were followed to raise a healthy crop in both normal and low P plots. Agro-morphological characters like days to 50\% flowering, plant height, panicle length, number of tillers per plant, number of productive tillers, Spikelet fertility (\%), 1000 seed weight, yield per plant, root length and root volume were recorded by adopting modified IRRI Standard Evaluation Scale (SES, 2002).

Root phenotyping of plants were carried out in low $\mathrm{P}$ and normal $\mathrm{P}$ plot of $\mathrm{BC}_{1} \mathrm{~F}_{2}$ and $\mathrm{ICF}_{2}$ generation. The plants were uprooted from field without damaging roots and washed with running water to remove soil for measuring root related parameters like root length and root volume. The average root length was measured from crown of the root to tip of the root, while the root volume was measured by using water displacement method, wherein the cleaned roots were placed in a measuring cylinder containing water and the rise in the level of water in the measuring level of water before placing the root in the measuring cylinder which represented the root volume in the unit of milliliters (Swamy et al. 2019; Anila et al. 2018). 


\section{Phenotypic screening of intercrossed lines for Bacterial blight resistance}

150 The parents and derived introgressed lines (ILs) were screened using bacterial culture of a virulent local isolate of the bacterial blight pathogen Xanthomonas oryzae pv. Oryzae (Xoo), IX-020 (Hyderabad, Telangana state, India). Xoo strain was cultured and stored as described by Laha et al. (2009). The bacterial culture inoculated at maximum tillering stage by following leaf clip inoculation method described by Kauffman et al. (1973). Inoculum of bacterial suspension containing $10^{8-9} \mathrm{cfu} / \mathrm{ml}$ was maintained. The lesion length on leaves was measured at 15 days after inoculation. Scoring was done based on percent diseased leaf area by adopting modified IRRI Standard Evaluation Scale, 2002. A total of $46 \mathrm{BC}_{1} \mathrm{~F}_{3}$ and $380 \mathrm{ICF}_{2}$ plants along with the parents were screened for bacterial leaf blight disease.

\section{Statistical analysis}

The agro-morphological and phenotypic data pertaining to ILs and parents evaluated under graded P plot and BB incidence were analyzed by calculating mean, analysis of variance (ANOVA) and least significance difference (5\% CD) by standard procedures (Gomez KA 1984) using IndoStat version 9.2 software and excel software. The analysis of background genome recovery percentage was assessed using GGT-2.0 software.

\section{Results}

\section{Introgression of Pup1 into APMS6B}

The low P sensitive female parent APMS6B was crossed with Pup 1 donor Kasalath and true $\mathrm{F}_{1}$ s were confirmed with Pupl specific PCR based dominant marker, K46-1. True positive nine $\mathrm{F}_{1} \mathrm{~s}$ were backcrossed with APMS6B to produce $23 \mathrm{BC}_{1} \mathrm{~F}_{1}$ plants. Genotyping of these $23 \mathrm{BC}_{1} \mathrm{~F}_{1}$ plants with Pupl specific marker K46-1 identified 12 positive plants. Co-dominant marker K20-1-1 (physical distance of $106 \mathrm{~kb}$ from the candidate gene for Pup 1) further used for genotyping of the positive plants which revealed that all 12 plants were in heterozygous for Pupl. The 12 positive plants were then screened with parental polymorphic SSR markers $(n=65)$ for identification of maximum recovery of the recurrent parent genome. Subsequently one plant with maximum recurrent parent genome $(81.15 \%)$ and positive for Pupl was identified and was selfed to produce $183 \mathrm{BC}_{1} \mathrm{~F}_{2}$ plants.

173 The $\mathrm{BC}_{1} \mathrm{~F}_{2}$ were phenotyped for yield traits under low $\mathrm{P}\left(<2 \mathrm{Kg} \mathrm{P}_{2} \mathrm{O}_{5} \mathrm{ha}^{-1}\right)$ plot at Research farm, ICAR-IIRR, Hyderabad and also genotyped with five Pupl specific markers (K46-1, K46-2, K48, K52 and K59). Advancement of selected $\mathrm{BC}_{1} \mathrm{~F}_{2}$ plants was carried out based on phenotypic similarity with APMS6B possessing Pupl loci. The 46 positive Pup1 plants were advanced to $\mathrm{BC}_{1} \mathrm{~F}_{3}$ and then to $\mathrm{BC}_{1} \mathrm{~F}_{4}$. Eleven plants were positive for all five dominant markers, 17 plants positive for four dominant markers, 10 plants were positive for three dominant markers and eight plants were positive for two dominant markers. Along with the foreground markers for Pupl, the derived lines were also screened for negative selection for fertility restoration $(R f)$ using candidate gene specific markers DRRM-RF310 for $R f 3$ and RMS-PPR-9-1 for $R f 4$ (Figure 2). Eleven positive plants showed complete maintenance ability for fertility markers and showed a distinctive tolerance under low $\mathrm{P}$ in comparison with recurrent parent were finally selected, however all the 11 derived lines were susceptible to bacterial blight disease.

Introgression of BB genes into Pup1 positive plant

184 Of the eleven Pupl positive $\mathrm{BC}_{1} \mathrm{~F}_{4}$ individuals, the line ATR-594-1 is phenotypically superior among the 
used as male parent for intercrossing with GU-2, a Near Isogenic Line (NIL) of APMS6B possessing Xa21 and $\mathrm{Xa} 38$ to obtain $\mathrm{ICF}_{1}$ plants. A total of $25 \mathrm{ICF}_{1}$ plants were genotyped with dominant functional markers $\mathrm{K} 46-1$, K462 and nine of them were identified positive for the presence of Pupl locus (Figure 4). They were later subjected to background selection using 65 parental polymorphic SSR markers and the plant BP-10 showed highest recurrent parent genome recovery percent of $88.29 \%$ (Figure 3) was identified and selfed to produce $\mathrm{ICF}_{2} \mathrm{~s}$. A total of $380 \mathrm{ICF}_{2}$ plants along with the parents (APMS6B, GU-2 \& Kasalath) were screened using virulent local strain of the bacterial blight pathogen, IX-020 (Hyderabad, Telangana state, India) of which 152 plants were found to be resistant with a lesion length of 1-4 cm and a score of 1-3 range. Susceptible checks, APMS6B and Kasalath showed susceptibility to the disease with a lesion length of $>8 \mathrm{~cm}$ and disease score of 9 , while resistant check APMS6B NIL (GU-2) was highly resistant to the disease with a lesion length of $<1 \mathrm{~cm}$ with a disease score of 1 . Phenotypically BB resistant 152 plants were genotyped for Pup-1 markers, where 36 plants showed positive variation for dominant markers, however only nine plants were positive for all the three Pup- 1 specific dominant markers K46-1, K46-2 and K-52 (Figure 4) and also phenotypically similar to the recurrent parent, APMS6B. Later these nine plants were subjected to recombinant selection with ESSR12-14.7 and ESSR12-17.4 which flank Pup-1 QTL on $12^{\text {th }}$ chromosome (Figure 5). Plants genotypically positive for Pupl were further subjected to genotyping with Xa21 specific marker, pTA248 and Xa38 specific marker, Os04g5350-1 (Figure 6). Four positive plants (viz., BP-10-1, BP-10-3, BP-10-5 and BP-10-15) possessing Pup-1, Xa21 and Xa38 gene combinations were forwarded to $\mathrm{ICF}_{3}$.

\section{Evaluation of parents and intercrossed lines for low phosphorus tolerance}

Parental lines (APMS6B, GU-2 and Kasalath), checks for susceptibility (IR 64) and tolerance (Swarna) and four

$\mathrm{ICF}_{3}$ progeny (positive for three genes $\mathrm{Xa21}, \mathrm{Xa38}$ and $\mathrm{Pup} 1$ ) lines were screened under two $\mathrm{P}$ levels viz., $<2 \mathrm{~kg}$ $\mathrm{P}_{2} \mathrm{O}_{5}$ ha $^{-1}\left(\right.$ low P) and $>25 \mathrm{~kg} \mathrm{P}_{2} \mathrm{O}_{5} \mathrm{ha}^{-1}$ (Normal condition) and the performance of them is presented in supplementary Figure 7.

\section{Characterization of Pup1 and BB positive introgression lines for yield and morphological traits}

The agronomic performance of the intercross-derived lines in $\mathrm{ICF}_{3}$ generation were on par with the recurrent parent for most of the traits examined (Table 2 and 3). The recipient parent, APMS6B recorded mean grain yield of 4.90 g/plant (low P) and $17.48 \mathrm{~g} /$ plant (normal), while the donor parent (Kasalath) recorded $8.07 \mathrm{~g} / \mathrm{plant}$ (low P) and $15.29 \mathrm{~g} / \mathrm{plant}$ (normal). The intercross derived lines viz., BP-10-1, BP-10-3, BP-10-5 and BP-10-15 had higher grain yields (8.61-11.90 g/plant in low P and 19.65-21.24 g/plant in normal) than the recurrent parent. Root length and root volume of improved lines showed higher values $(15.75-24.50 \mathrm{~cm}$ and $15.00-32.50 \mathrm{ml})$ than recurrent parent APMS6B $(7.67 \mathrm{~cm}$ and $8.33 \mathrm{ml})$. All the four selected lines showed phenotypic similarity with the recipient parent (APMS6B) (Figure 7).

Under low P condition, the improved lines with Pup1 and Xa21 \& Xa38 recorded significant yield advantage over the recurrent parent APMS6B. These derived lines had exhibited a yield reduction by $43.99 \%$ to 56.65\% comparatively lesser to APMS6B (71.97\%). Under low P condition, the plant height of derived lines had an upper hand over the recurrent parent ranged between $64-68.25 \mathrm{~cm}$ and increase in productive tillers from 6 to 11.5; panicle 
length increased from 17.5 to $22.0 \mathrm{~cm}$, spikelet fertility from 63.38 to $75.33 \%$. There has been an increase in 1000 seed weight from 14.45 to $16.03 \mathrm{~g}$. The yield stability and stress susceptibility indices were higher in contrast to APMS6B i.e., between 0.56- 0.43 and $0.76-0.98$ respectively (Table 4). Based on the agronomic performances of the introgressed lines it can be understood that under low $\mathrm{P}$ condition these lines had been effectively tolerant to low $\mathrm{P}$ levels and had been better in all yield traits compared to APMS6B.

Under normal soil P plot, there was non-significant difference found in Pupl introgressed lines in comparison with APMS6B for days to 50\% flowering (84.33-94.67 days) and plant height (67.67- $74 \mathrm{~cm})$. But we have an observed a remarkable difference in panicle length $(20.83-21.67 \mathrm{~cm})$, an increase in the number of total tillers and productive tillers of 12.33-15.67 and 12.02-14.67 respectively. The spikelet fertility has gone up to 77.30 to $83.34 \%$ and an increase from $19 \mathrm{~g}$ to $19.62 \mathrm{~g}$ over 1000 seed weight. The major significant characters observed were the improvement in root length $(16.50-22.67 \mathrm{~cm})$ and root volume $(20.33-29.33 \mathrm{ml})$ and yield per plant up to 19.65 21.24g. The distinctness, uniformity and stability (DUS) characters of introgressed lines were similar to recurrent parent.

\section{Discussion}

The outreach of hybrid rice technology in India and all over the rice growing states of Asia had tasted success in terms of heterotic yield when compared to inbred varieties. However, most of the commercial rice hybrids grown in India and elsewhere are highly vulnerable to many biotic and abiotic stresses; one among them is low soil P stress, where $49 \%$ of Indian soils are deficit and 90\% dependency in importing P based fertilizers (Hasan 1996; Swamy et al. 2019). Therefore, our attempt was to improve APMS6B, the maintainer line for its tolerance to low soil P by targeted introgression of Pupl, a major QTL from Kasalath and introgression of Xa21 and Xa38, a major bacterial blight resistance gene, with a great inception for improvement of maintainer line among many of biotic and abiotic stresses through MABB.

\section{Identification of Pup1 introgression lines in the background of APMS6B}

246 The donor, Kasalath was initially identified in a screening of 30 diverse rice genotypes in a P-deficient soil in Japan under rain-fed conditions. The gene OSPSTOL1 is known to enhance P uptake in rice (Wissuwa and Ae 2001; Chin et al. 2009). The phenotypic data derived from Nipponbare contrasting near isogenic lines (NILs) with and without the QTL showed that Pupl increases P uptake (Wissuwa et al. 2002; Wissuwa and Ae 2001) and confers a significant yield advantage ( 2 to 4 fold) in pot experiments under different P-deficient soil types and environments (Chin et al. 2009). The Pupl derived donor ATR 594-1 is derivative of $\mathrm{BC}_{1} \mathrm{~F}_{3}$ line of limited backcrossing of APMS6B with Kasalath (a perfect maintainer) facilitates adaptive introgression (Rieseberg LH. 1993) of more functional alleles of Kasalath and in turn enhances genetic diversity. The GU-2, (an improved version of APMS6B possessing Xa21 \& Xa38) was intercrossed with ATR 594-1. The approach of MABB involving foreground, recombinant and background selection was adopted in the study for quick transfer of Pupl, Xa21 and Xa38 into was limited to just two using $\mathrm{MABB}$ coupled with stringent phenotyping selection procedures. At each intercross 
selfing generation, the dominant functional markers, K46-1 and K46-2 were used to monitor the segregation of Pup1. Two SSR markers, viz., ESSR12-14.7 and ESSR12-17.4 were employed for recombinant selection.

260 Four promising $\mathrm{ICF}_{3}$ lines with maximum of APMS6B genome to an extent of 87-89\%, indicates the efficacy of stringent marker assisted backcross breeding and also the fact that limited backcrossing was a great success in the present study. In addition to deploying dominant, functional markers, i.e. K46-1and K46-2, to reconfirm the derived $\mathrm{ICF}_{2}$ lines, we also employed a recombinant selection between the flanking marker and Pupl. $\mathrm{ICF}_{2}$ plants showing phenotypically resistant to BB and Pup-1 positive were genotyped for Xa21 specific marker, pTA248 and Xa38 specific marker, Os04g5350-1. Four plants positive for all three loci i.e. Pup-1 QTL and Xa21 and Xa38 genes were selected and selfed for generation advancement, these findings are in confirmation with (Chithrameenal et al. 2018; Swamy et al. 2020).

\section{Identification of low $P$ tolerant $B B$ resistant lines}

Bacterial blight is an important disease affecting rice cultivation in major rice-growing areas of Asia (Mew 1993) $X a 21$ is a broad-spectrum resistance gene derived from $O$. longistaminata widely used in gene pyramiding programme (Gopalakrishnan et al. 2008; Sundaram et al. 2008; Basavaraj et al. 2010; Hari et al. 2011) The Xa21 gene was introduced to cultivar PR106 in India because it showed resistance to 17 Xoo strains in Punjab, India (Singh et al. 2001). Xa21 is considered as the most effective gene that show effective resistance to $88 \%$ of the Xoo strains in India (Mishra et al. 2013). However, evidence of virulent strains for Xa21 for BB in India was also reported (Yugander et al. 2017; Mishra et al. 2013). Another BB gene Xa38 provides a high level of resistance to most of the prevailing BB races of Xoo from Punjab state of India (Cheema et al. 2008). The combination of Xa21 and $\mathrm{Xa} 38$ in the selected advanced back cross derived lines (BDLs) exhibited broad-spectrum BB resistance when compared to the parental lines containing only Xa21 developed in many earlier studies (Chen et al., 2000; Hari et al., 2011). Yugander et al. (2018) reported improved versions of the stable maintainer line, APMS6B, which possess a very high level of BB resistance (conferred by two major, dominant BB resistance genes Xa21 and Xa38) and marginally higher yields as compared to the recurrent parent. BB resistance genes Xa21 and Xa13 along blast resistant genes Pi2 and Pi54 were also successfully introgressed in Pusa Basmati 1509 (Sagar et al. 2020). To develop durable BB resistance in one of the Indian elite rice variety Samba Mahsuri (Sundaram et al. 2008) introgressed $\mathrm{Xa}$ 21, xal3 and $x a$ 5. The resultant introgressed variety know as Improved Samba Mahsuri became very much popular among rice farmers and now grown in an area of 2.5 Lakh hectare. All these studies stage the importance for development of disease resistance rice varieties in the crux. Several BB resistant genes have been mapped and a combination of two genes (Xa2l and Xa38) is reported to be effective against bacterial blight isolates in major rice growing regions of the world. Incorporation of Xa21 and Xa38 genes together will pave resistance in a wider context in majority of prevailing races (Yugander et al. 2018). Our study demonstrated the efficiency of marker-assisted backcross breeding combined with phenotyping in developing rice genotypes with improved disease resistance and enhanced level of tolerance to P starvation. and BP-10-15), which were very much similar to APMS6B in terms of agro-morphological traits, grain quality and possessing recurrent parent genome recovery ranging from 87 to $89 \%$, were evaluated in a plot having optimum soil 
P level and also in the low soil P plot, during Kharif 2018, which have most of the traits similar to or better than the original recurrent parent. Their advanced intercross-derived lines were not analyzed for the other genes/QTLs (such as drought tolerance), which might have contributed for significant improvement in few of the traits other than low soil P tolerance.

Use of molecular markers spread across the rice genome helped us in recovering desirable attributes like early flowering, medium slender grain type and high yield traits of APMS6B (with 89\% recurrent parent genome recovery) within one backcross and intercross thus saving time and resources in the present study. Similar investigations were published for marker-assisted gene pyramiding in different rice varieties for various stress conditions (Chithrameenal et al. 2018; Swamy et al. 2020).

The introgressed lines had a delayed flowering under low P compared to normal soil conditions, however earlier than original APMS6B parent. This could be the adaptive mechanism of plants for low $\mathrm{P}$ to provide maximum yield and biomass (Swamy et al. 2020) (Nord \& Lynch. 2008). Generally, plants respond to nutrient stress by shortening its life cycle, delay flowering to attain threshold nutrient uptake for flowering and less biomass and few number seeds. Due to increased uptake of P and better utilization by Pupl introgressed lines makes to recover phenological instability noticed in low P condition (Wissuwa et al. 2002; Chin et al. 2011; Gamuyao et al. 2012). Under the low soil $\mathrm{P}$ condition, significant improvement in plant height, panicle length, total and productive tillers, spikelet fertility, root length, root volume and grain yield per se among the Pupl introgressed lines relative to the recipient parent APMS6B (Swamy et al. 2020; Anila et al. 2018; Magalhaes et al. 2017; Chithrameenal et al. 2018). However, no significant difference for yield and associated traits noticed in introgressed lines and perform on par with recurrent parent APMS6B under normal soil phosphorus condition. The presence of phosphorus responsive gene OSPSTOL1 (Pup1) in introgressed lines facilitates the effectual root system like root length and root volume which in turn helps in improvement of grain yield under P deficit soil as reported by Gamuyao et al. (2012) and Yugandhar et al. (2017). Positive and significant association of root length and volume in derived lines noticed in terms of tolerance to low $\mathrm{P}$ and grain yield and similar observations were reported by earlier workers (Kale et al. 2021). The Pup1 possessed lines with modified root architecture and morphology facilitate exploration and adaptive mechanism to access $\mathrm{P}$ beyond the rhizosphere when bioavailable $\mathrm{P}$ is limited under low $\mathrm{P}$ plot. but yield stability and stress tolerance index calculated was higher than APMS6B (Yugander et al. 2018). A single line BP10-15 performed better with respect to number of productive tillers per plant, panicle length, spikelet fertility, 1000 seed weight and grain yield per plant in both normal and low soil P plots. Improving parental lines for phosphorous tolerance and high P usage efficiency can be a breakthrough for reduced usage of phosphate fertilizers. Such development not only reduces the cost of cultivation but also the development of hybrids that yields more under acidic, alkaline soils where low $\mathrm{P}$ conditions are frequently noticed. The improved maintainers for Pupl tolerance and BB resistance can be used as donors for future breeding programme. Agricultural sustenance in rice production with heterotic yield can be achieved by MABB with the improved hybrid DRRH-3. Improvement of parental lines in rice for biotic and abiotic stress tolerance will be an additional uplift for hybrid rice cultivation in stress prone unfavorable environments. 


\section{References}

Amante-Bordeos A, Sitch LA, Nelson R, et al (1992) Transfer of bacterial blight and blast resistance from the tetraploid wild rice Oryza minuta to cultivated rice, Oryza sativa. Theor Appl Genet 1992 843 84:345-354. https://doi.org/10.1007/BF00229493

Anila M, Mahadeva Swamy HK, Kale RR, et al (2018) Breeding lines of the Indian mega-rice variety, MTU 1010, possessing protein kinase OsPSTOL (Pup1), show better root system architecture and higher yield in soils with low phosphorus. Mol Breed 20183812 38:1-9. https://doi.org/10.1007/S11032-018-0903-1

Basavaraj SH, Singh VK, Singh A, et al (2010) Marker-assisted improvement of bacterial blight resistance in parental lines of Pusa RH10, a superfine grain aromatic rice hybrid. Mol Breed 26:293-305. https://doi.org/10.1007/s11032-010-9407-3

Bhasin H, Bhatia D, Raghuvanshi S, et al (2012) New PCR-based sequence-tagged site marker for bacterial blight resistance gene Xa38 of rice. Mol Breed 2012301 30:607-611. https://doi.org/10.1007/S11032-011-9646-Y

Cheema KK, Grewal NK, Vikal Y, Sharma R, Lore JS, Das A, Bhatia D, Mahajan R, Gupta V, Bharaj TS SK (2008) A novel bacterial blight resistance gene from Oryza nivara mapped to $38 \mathrm{~kb}$ region on chromosome $4 \mathrm{~L}$ and transferred to Oryza sativa L. Genet Res (Camb) 90(5):397-407

Chin JH, Gamuyao R, Dalid C, et al (2011) Developing Rice with High Yield under Phosphorus Deficiency: Pup1 Sequence to Application. Plant Physiol 156:1202-1216. https://doi.org/10.1104/PP.111.175471

Chin JH, Lu X, Haefele SM, et al (2009) Development and application of gene-based markers for the major rice QTL Phosphorus uptake 1. Theor Appl Genet 20091206 120:1073-1086. https://doi.org/10.1007/S00122009-1235-7

Chithrameenal K, Alagarasan G, Raveendran M, et al (2018) Genetic enhancement of phosphorus starvation tolerance through marker assisted introgression of OsPSTOL1 gene in rice genotypes harbouring bacterial blight and blast resistance. PLoS One 13:e0204144. https://doi.org/10.1371/JOURNAL.PONE.0204144

Fageria NK, Baligar VC (1997) Upland rice genotypes evaluation for phosphorus use efficiency. J Plant Nutr 20:499-509. https://doi.org/10.1080/01904169709365270

Fageria NK, Morais OP, Baligar VC, Wright RJ (1988a) Response of rice cultivars to phosphorus supply on an oxisol. Fertil Res 1988 163 16:195-206. https://doi.org/10.1007/BF01051370

Fageria NK, Wright RJ, Baligar VC (1988b) Rice cultivar evaluation for phosphorus use efficiency. Plant Soil 1988 1111 111:105-109. https://doi.org/10.1007/BF02182043

Gamuyao R, Chin JH, Pariasca-Tanaka J, et al (2012) The protein kinase Pstoll from traditional rice confers tolerance of phosphorus deficiency. Nat 20124887412 488:535-539. https://doi.org/10.1038/nature11346

Gomez KA and GA (1984) Statistical Procedures for Agricultural Research. John Wiley Sons Inc, New York 2nd Editio:75-165

Gopalakrishnan S, Sharma RK, Rajkumar KA, et al (2008) Integrating marker assisted background analysis with foreground selection for identification of superior bacterial blight resistant recombinants in Basmati rice. Plant Breed 127:131-139. https://doi.org/10.1111/J.1439-0523.2007.01458.X

Hari Y, Srinivasarao K, Viraktamath BC, et al (2011) Marker-assisted improvement of a stable restorer line, KMR- 
3R and its derived hybrid KRH2 for bacterial blight resistance and grain quality. Plant Breed 130:608-616. https://doi.org/10.1111/J.1439-0523.2011.01881.X

Hasan R (1996) Phosphorus Status of Soils in India. Better Crop Int 10:4-5

Heuer S, Gaxiola R, Schilling R, et al (2017) Improving phosphorus use efficiency: a complex trait with emerging opportunities. Plant J 90:868-885. https://doi.org/10.1111/TPJ.13423

Heuer S, Lu X, Chin JH, et al (2009) Comparative sequence analyses of the major quantitative trait locus phosphorus uptake 1 (Pup1) reveal a complex genetic structure. Plant Biotechnol J 7:456-471. https://doi.org/10.1111/J.1467-7652.2009.00415.X

Hittalmani S, Parco A, Mew T V., et al (2000) Fine mapping and DNA marker-assisted pyramiding of the three major genes for blast resistance in rice. Theor Appl Genet 20001007 100:1121-1128. https://doi.org/10.1007/S001220051395

Kale RR, Rani CVD, Anila M, et al (2021) Novel major QTLs associated with low soil phosphorus tolerance identified from the Indian rice landrace, Wazuhophek. PLoS One 16:e254526. https://doi.org/10.1371/JOURNAL.PONE.0254526

Kauffman, H.E., A.P.K. Reddy SPYH and SDM (1973) An improved technique for evaluating resistance of rice varieties to Xanthomonas oryzae. Plant Dis Rep 57:537-541

Khush GS, Mackill DJ SG (1989) Breeding rice for resistance to bacterial blight. In: Banta SJ, editor. Bacterial blight of rice. Los Banos Int Rice Res Institute; 207-217

Kim S-M, Suh J-P, Qin Y, et al (2015) Identification and fine-mapping of a new resistance gene, Xa40, conferring resistance to bacterial blight races in rice (Oryza sativa L.). Theor Appl Genet 201512810 128:1933-1943. https://doi.org/10.1007/S00122-015-2557-2

Laha GS, Reddy CS, Krishnaveni D, Sundaram RM, Srinivas PM, Ram T, Muralidharan K VB (2009) Bacterial blight of rice and its management. DRR Tech Bull (41):37:

Magalhaes J V., de Sousa SM, Guimaraes CT, Kochian L V. (2017) The role of root morphology and architecture in phosphorus acquisition: physiological, genetic, and molecular basis. Plant Macronutr Use Effic Mol Genomic Perspect Crop Plants 123-147. https://doi.org/10.1016/B978-0-12-811308-0.00007-7

Mew TW (1993) Focus on Bacterial Blight of Rice. Plant Dis 77:5. https://doi.org/10.1094/PD-77-0005

Mew TW (1987) Current Status and Future Prospects of Research on Bacterial Blight of Rice. http://dx.doi.org/101146/annurev.py25090187002043 25:359-382. https://doi.org/10.1146/ANNUREV.PY.25.090187.002043

Mishra D, Vishnupriya MR, Anil MG, et al (2013) Pathotype and Genetic Diversity amongst Indian Isolates of Xanthomonas oryzae pv. oryzae. PLoS One 8:e81996. https://doi.org/10.1371/JOURNAL.PONE.0081996

Ogawa T (1993) Methods and strategy for monitoring race distribution and identification of resistance genes to bacterial leaf blight (Xanthomonas campestris pv. oryzae) in rice. JARQ 27:71-80

Rieseberg LH WJ (1993) Introgression and its consequences in plants. Hybrid zones and the evolutionary process. 70:109

Ronald PC, Albano B, Tabien R, et al (1992) Genetic and physical analysis of the rice bacterial blight disease 
resistance locus, Xa21. Mol Gen Genet MGG 19922361 236:113-120. https://doi.org/10.1007/BF00279649

Rose T, Liu L, Wissuwa M (2013) Improving phosphorus efficiency in cereal crops: Is breeding for reduced grain phosphorus concentration part of the solution? Front Plant Sci 0:444. https://doi.org/10.3389/FPLS.2013.00444

Sagar V, Dhawan G, Gopala Krishnan S, et al (2020) Marker assisted introgression of genes governing resistance to bacterial blight and blast diseases into an elite Basmati rice variety, 'Pusa Basmati 1509.' Euphytica 2020 2161 216:1-18. https://doi.org/10.1007/S10681-019-2549-4

Senguttuvel P, Revathi P, Kemparaju KB, Sruthi K, Sadath Ali M, KoteswaraRao P HPA (2019) Rice Hybrids Released in India. Compendium No. 103/2019. ICAR IIRR, Rajendranagar, Hyderabad-500 030. India. p. 127. p 127

Singh S, Sidhu JS, Huang N, et al (2001) Pyramiding three bacterial blight resistance genes (xa5, xa13 and Xa21) using marker-assisted selection into indica rice cultivar PR106. Theor Appl Genet 20011026 102:1011-1015. https://doi.org/10.1007/S001220000495

Sundaram RM, Vishnupriya MR, Biradar SK, et al (2008) Marker assisted introgression of bacterial blight resistance in Samba Mahsuri, an elite indica rice variety. Euphytica 2007 1603 160:411-422. https://doi.org/10.1007/S10681-007-9564-6

Swamy HKM, Anila M, Kale RR, et al (2020) Marker assisted improvement of low soil phosphorus tolerance in the bacterial blight resistant, fine-grain type rice variety, Improved Samba Mahsuri. Sci Reports 2020101 10:114. https://doi.org/10.1038/s41598-020-78186-5

Swamy HKM, Anila M, Kale RR, et al (2019) Phenotypic and molecular characterization of rice germplasm lines and identification of novel source for low soil phosphorus tolerance in rice. Euphytica 20192157 215:1-15. https://doi.org/10.1007/S10681-019-2443-0

WEBECK E, MATSUBAE K, NAKAJIMA K, et al (2014) Analysis of Phosphorus Dependency in Asia. Sociotechnica 11:119-126. https://doi.org/10.3392/sociotechnica.11.119

Wissuwa M, Ae N (2001) Genotypic variation for tolerance to phosphorus deficiency in rice and the potential for its exploitation in rice improvement. Plant Breed 120:43-48. https://doi.org/10.1046/J.1439-0523.2001.00561.X

Wissuwa M, Wegner J, Ae N, Yano M (2002) Substitution mapping of Pup1: a major QTL increasing phosphorus uptake of rice from a phosphorus-deficient soil. Theor Appl Genet 2002 1056 105:890-897. https://doi.org/10.1007/S00122-002-1051-9

Wissuwa M, Yano M, Ae N (1998) Mapping of QTLs for phosphorus-deficiency tolerance in rice (Oryza sativa L.). Theor Appl Genet 1998 975 97:777-783. https://doi.org/10.1007/S001220050955

Yugander A, Sundaram RM, Ladhalakshmi D, et al (2017) Virulence profiling of Xanthomonas oryzae pv. oryzae isolates, causing bacterial blight of rice in India. Eur J Plant Pathol 20171491 149:171-191. https://doi.org/10.1007/S10658-017-1176-Y

Yugander A, Sundaram RM, Singh K, et al (2018) Improved versions of rice maintainer line, APMS 6B, possessing two resistance genes, Xa21 and Xa38, exhibit high level of resistance to bacterial blight disease. Mol Breed 2018388 38:1-14. https://doi.org/10.1007/S11032-018-0853-7 
Yugandhar P, Basava R, ... SD-AJ of, 2017 undefined (2017) Identifying markers associated with yield traits in Nagina22 rice mutants grown in low phosphorus field or in alternate wet/dry conditions. search.informit.org 548:1835-2707. https://doi.org/10.21475/ajcs.17.11.05.p372

Zheng KL, Huang N, Bennett J KG (1995) PCR-based marker-assisted selection in rice breeding. IRRI Discuss Pap er.

Zhou YL, Uzokwe VNE, Zhang CH, et al (2011) Improvement of bacterial blight resistance of hybrid rice in China using the Xa23 gene derived from wild rice (Oryza rufipogon). Crop Prot 30:637-644. https://doi.org/10.1016/J.CROPRO.2010.12.002

\section{Author Contribution Statement}

MN and SP conceived, planned and designed study. MN, Be.P, VJ, NP and MY conducted experiments. MN and SP analyzed the data and wrote the manuscript. AMS, KKB, KMB, LGS, GC, GR, ASH, Br.P, TMD and MKR critically edited the manuscript. SRM helped in coordination of the study and edited final draft of the manuscript.

\section{Conflict of interest statement}

The authors declare that they have no conflict of interest.

\section{Legends of Tables and Figures}

Table 1. Details on markers used in foreground selection for identification of phosphorus starvation tolerance and bacterial blight resistance.

Table 2: Evaluation of $\mathrm{ICF}_{3}$ lines (positive for Pup-1, Xa-21 and $\mathrm{Xa-38}$ genes) in Normal soil P plot at ICAR-IIRR, during, Kharif-2018.

Table 3. Evaluation of $\mathrm{ICF}_{3}$ lines (positive for Pup-1, Xa-21 and $X \boldsymbol{a}-\mathbf{3 8}$ genes) in low soil P plot at ICAR-IIRR during Kharif-2018

Table 4: Stress indices calculated for Pup-1 introgressed APMS-6B $\mathrm{ICF}_{3}$ lines based on per plant yield under normal and Low soil P conditions.

Figure 1: Crossing plan followed for the introgression of Pup-1 and Xa21+ Xa38 into APMS6B.

Figure 2: Genotyping of $\mathrm{BC} 1 \mathrm{~F} 3$ derived lines from cross APMS6B and Kasalath for Rf4 and Rf3 gene specific markers.

Figure 3: Graphical representation of Background selection on ICF2

Figure 4: Foreground selection for Pup1 among ICF2 plants using Pup1 specific markers K46-1, K46-2 and K-52.

Figure 5: Recombinant selection of Pup1 positive ICF2 plants with the flanking marker ESSR12-14.7 and ESSR$12-17.4$

Figure 6: Genotypic selection for Bacterial blight disease among ICF2 plants using Xa21 and Xa38 gene specific markers such as pTA-248 and Oso4g53050-1, respectively. 
Figure 7: A. Performance of Pup1 introgressed lines under low P (<2 kg P2O5 ha-1) and B. Normal conditions ( $>25$ kg P2O5 ha-1); C. Root length of parents and ILs under low P condition; D. Panicles of parents and Pup1 introgressed lines; E. Scoring of BB inoculated leaf. 


\section{APMS6B $\times$ KASALATH (Recurrent Parent) (Donor) 凤}

APMS6B $\times \mathrm{F}_{1}$

?

$\mathrm{BC}_{1} \mathrm{~F}_{1}$

$\checkmark$

$\mathrm{BC}_{1} \mathrm{~F}_{2}$

凤

Improved APMS6B $\quad \times \mathrm{BC}_{1} \mathrm{~F}_{3}$

$(+X a 21 \&$ Xa38)

(+ Pup1)

ป

$\mathrm{ICF}_{1}$

$\checkmark$

$\mathrm{ICF}_{2}$

$\checkmark$

$\mathrm{ICF}_{3}$

Figure 1: Crossing plan followed for the introgression of Pup-1 and Xa21+ Xa38 into APMS6B. 


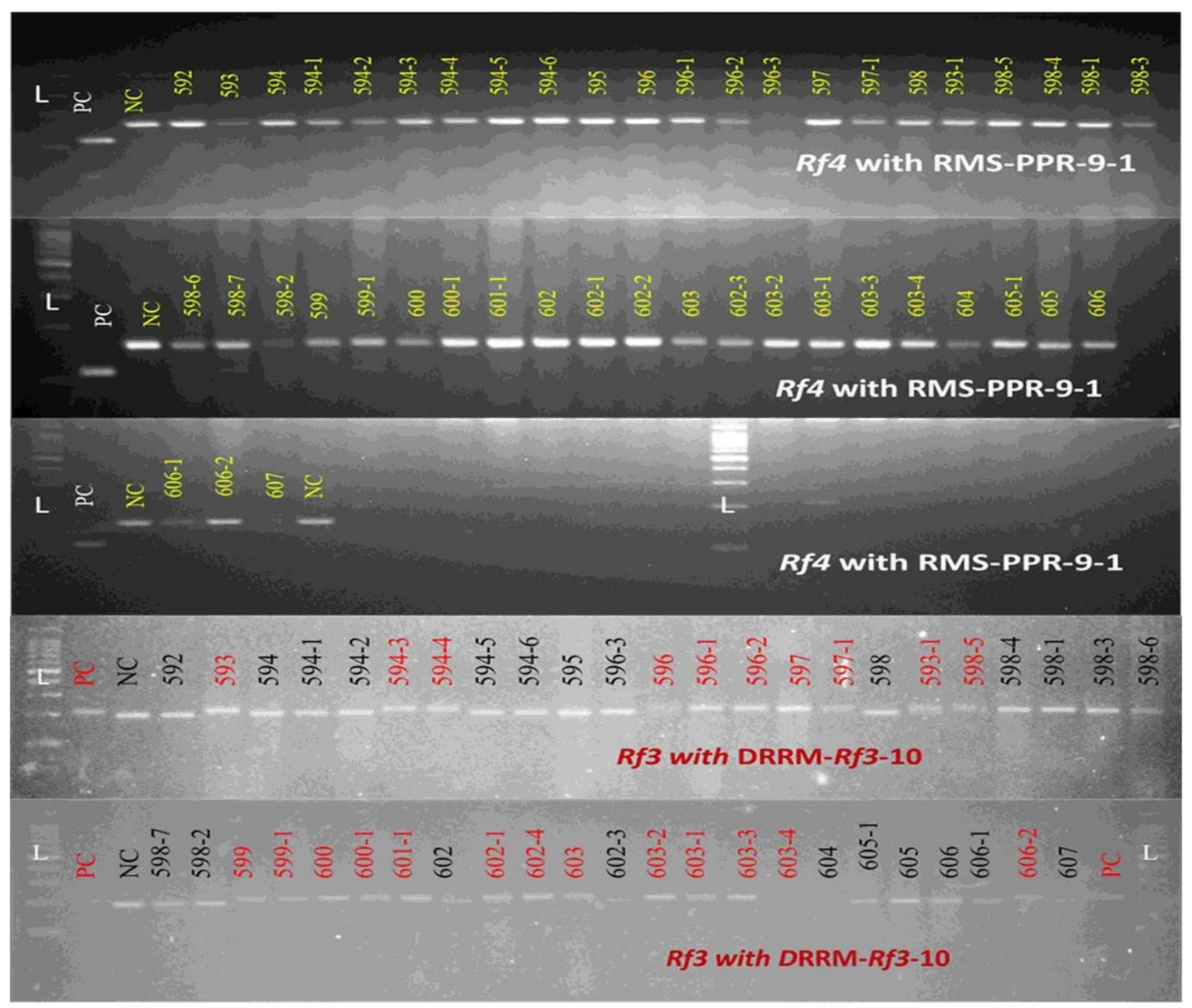

L- 100 bp ladder, PC- positive check (KMR-3R) and NC- negative check (APMS-6B); Numbers$\mathrm{BC}_{1} \mathrm{~F}_{3 \mathrm{~S}}$ derived lines from cross APMS-6B and Kasalath. Yellow and black colour font in entries indicates the absence of respective restoration of fertility (viz., $R f 4$ with RMS-PPR-9-1 and $R f 3$ with DRRM-Rf3-10, respectively) and red colour entries indicate presence of DRRM-Rf3-10 in genotypes.

Figure 2: Genotyping of BC1F3 derived lines from cross APMS6B and Kasalath for Rf4 and Rf3 gene specific markers. 


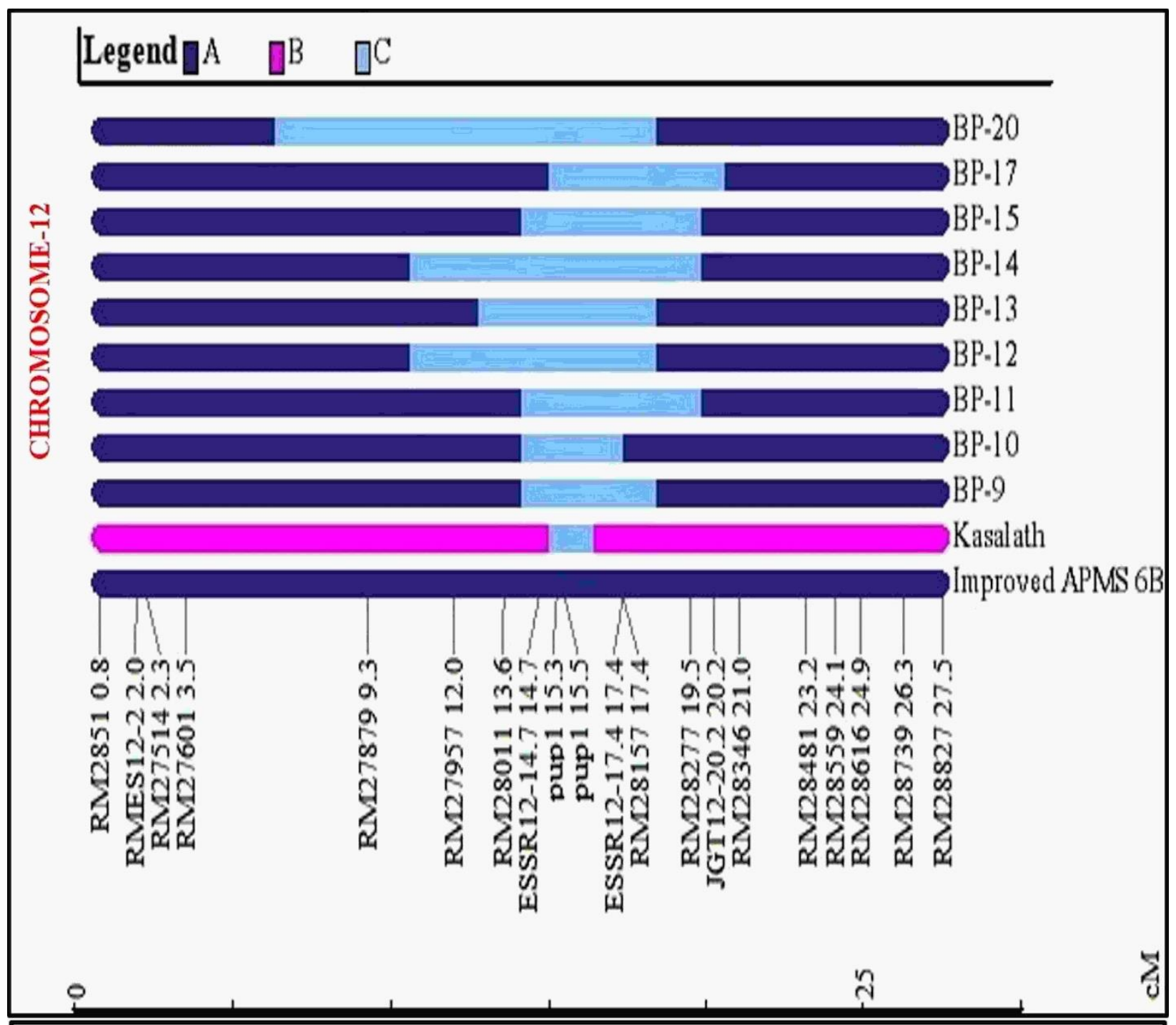

A)- Improved APMS6B; B)- Kasalath; C)- Pup-1 Locus

The $\mathrm{ICF}_{1}$ plants BP-9, BP-10, BP-11, BP-12, BP-13, BP-14 BP-15, BP-17 and BP-20 had a varying per cent of genome recovery. The plant BP-10 which had maximum genome recovery (88.29\%) of recurrent parent Improved APMS6B genome was selected and selfed to produce $\mathrm{ICF}_{2}$.

Figure 3: Graphical representation of Background selection on ICF2 


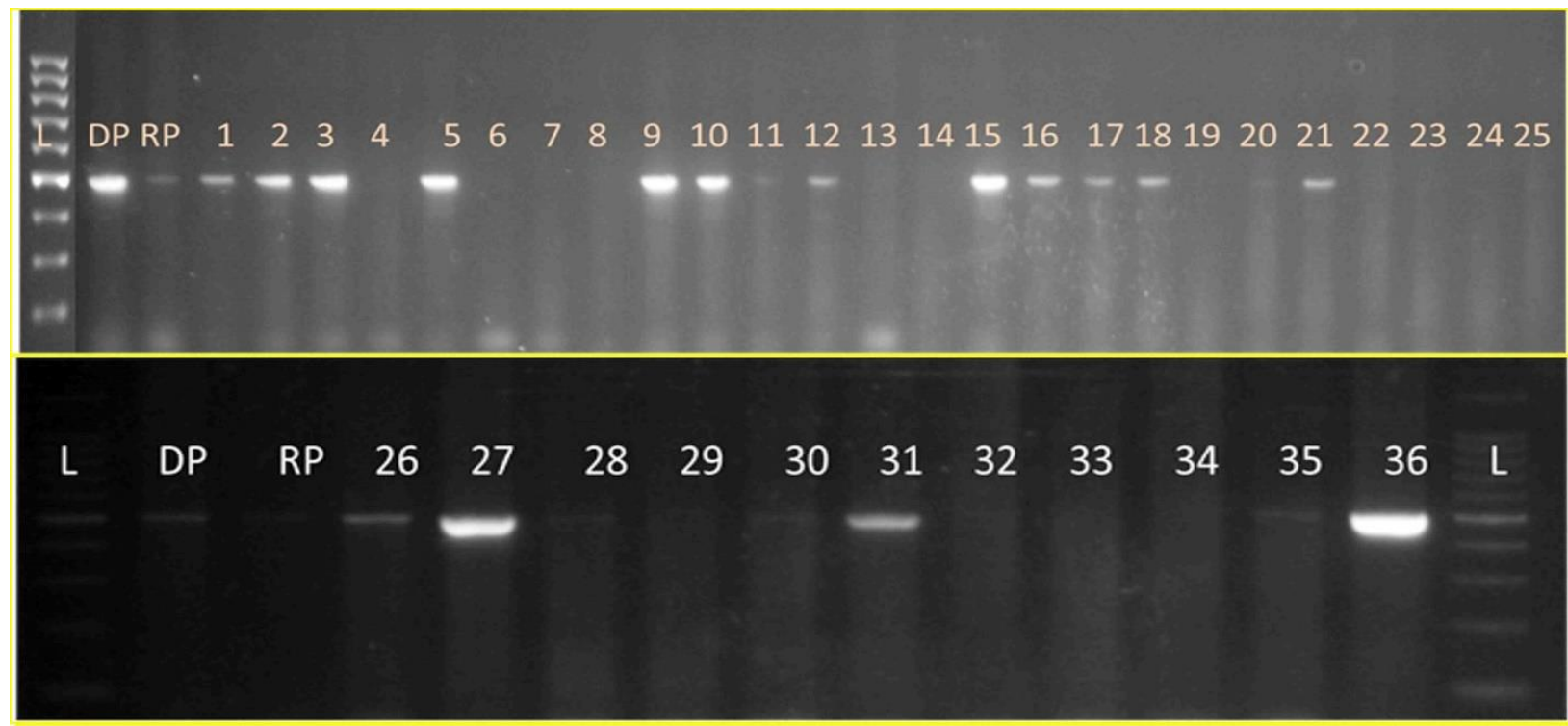

L- 100 bp ladder, DP- Kasalath (Donor), RP- GU-2 (APMS6B NILs) (Recipient), Presence of bands indicates $\mathrm{ICF}_{2}$ possessing Pup-1 


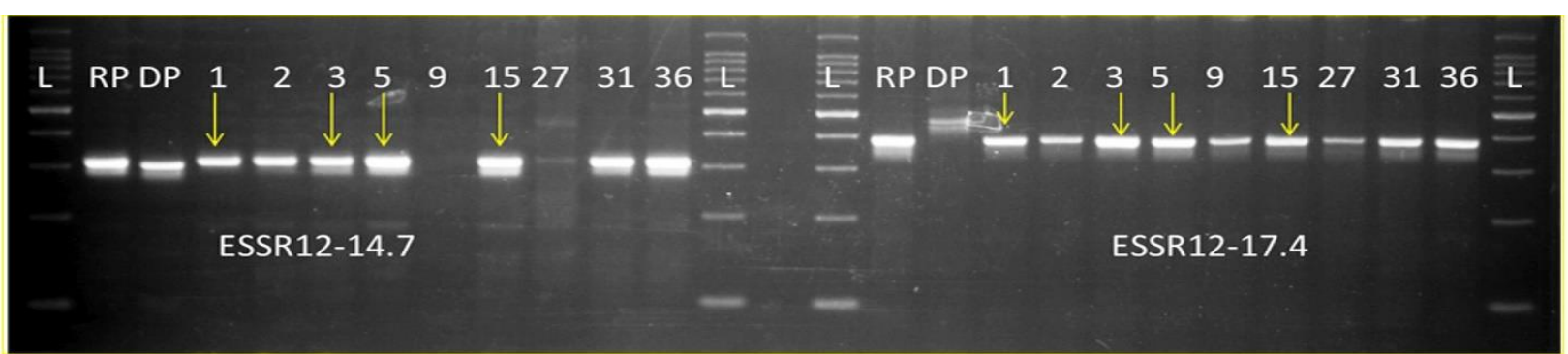

L- 100 bp ladder, RP- GU-2 (APMS-6B NILs), DP- Kasalath, 1 to $36-$ ICF $_{1}$ plants and Arrows indicate homozygous for 504 APMS-6B locus flanking the QTL nearby

505

506 Figure 5: Recombinant selection of Pup1 positive ICF2 plants with the flanking marker ESSR12-14.7 and ESSR$507 \quad 12-17.4$ 


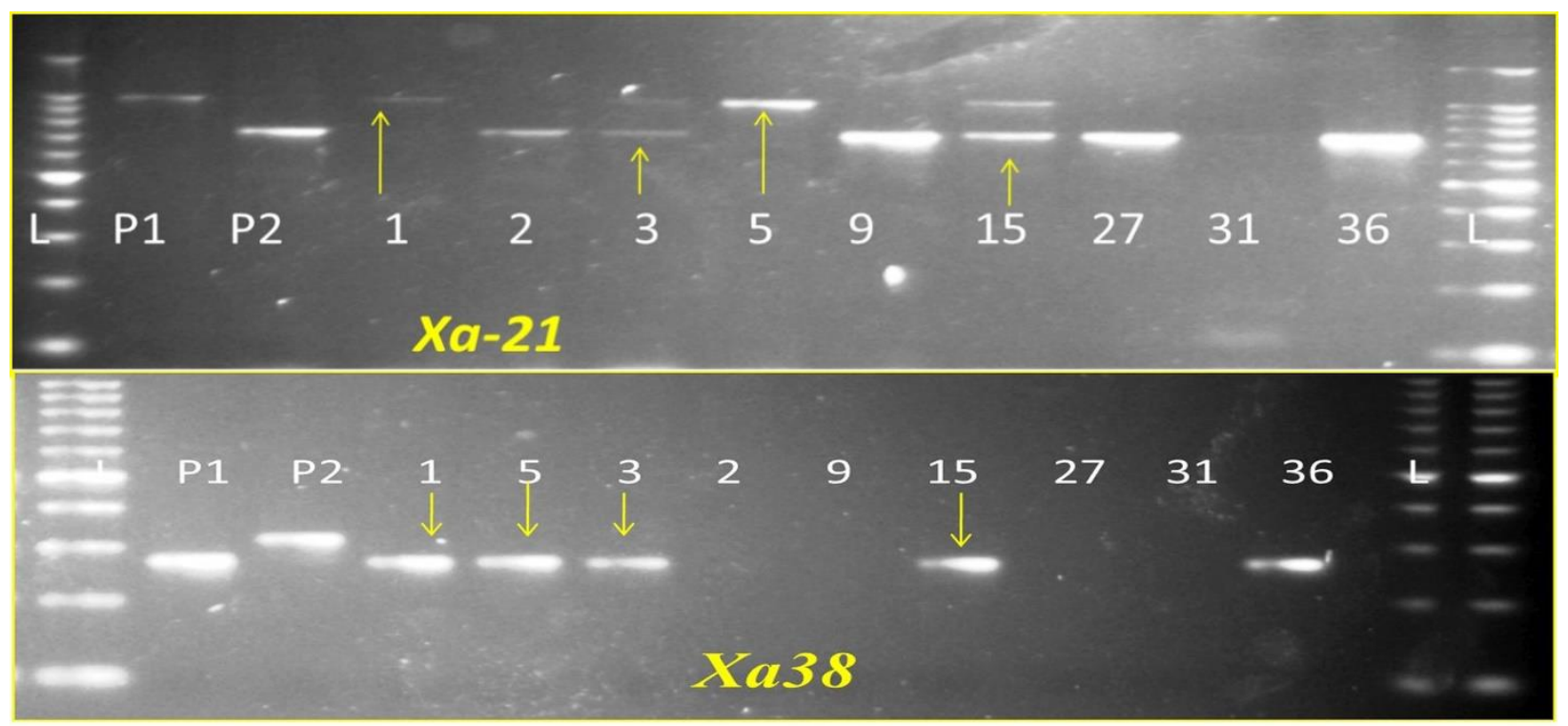

511 Figure 6: Genotypic selection for Bacterial blight disease among ICF2 plants using Xa21 and Xa38 gene specific 512 markers such as pTA-248 and Oso4g53050-1, respectively. 

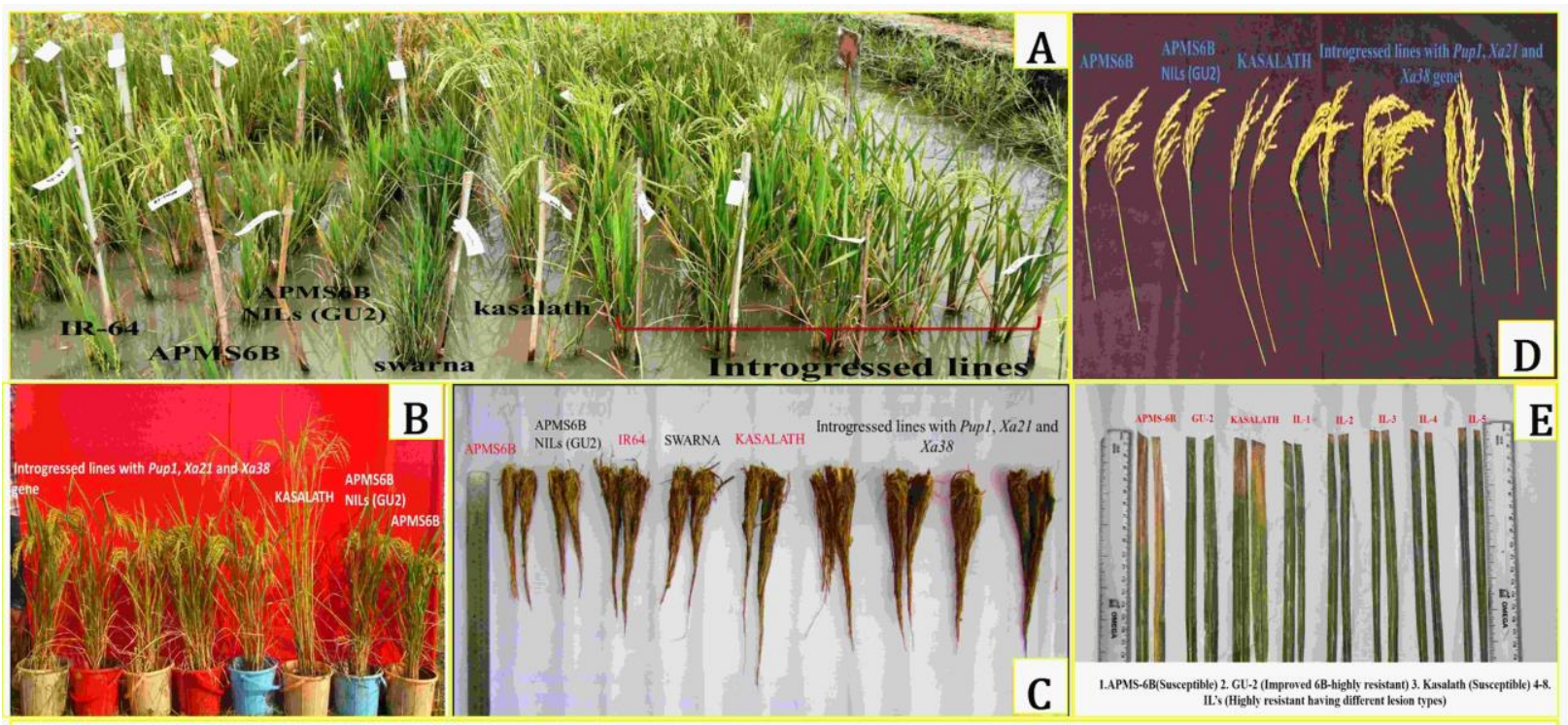

A. Performance of Pup1 introgressed lines under low P $\left(<2 \mathrm{~kg} \mathrm{P}_{2} \mathrm{O}_{5}\right.$ ha- $\left.^{-1}\right)$ and B. Normal conditions ( $>25 \mathrm{~kg} \mathrm{P}_{2} \mathrm{O}_{5}$ ha-1 $^{-1}$ ); C. Root length of parents and ILs under low P condition; D. Panicles of parents and Pup1 introgressed lines; E. Scoring of BB inoculated leaf

Figure 7: A. Performance of Pup1 introgressed lines under low P ( $<2 \mathrm{~kg}$ P2O5 ha-1) and B. Normal conditions ( $>25$ kg P2O5 ha-1); C. Root length of parents and ILs under low P condition; D. Panicles of parents and Pup1 introgressed lines; E. Scoring of BB inoculated leaf. 


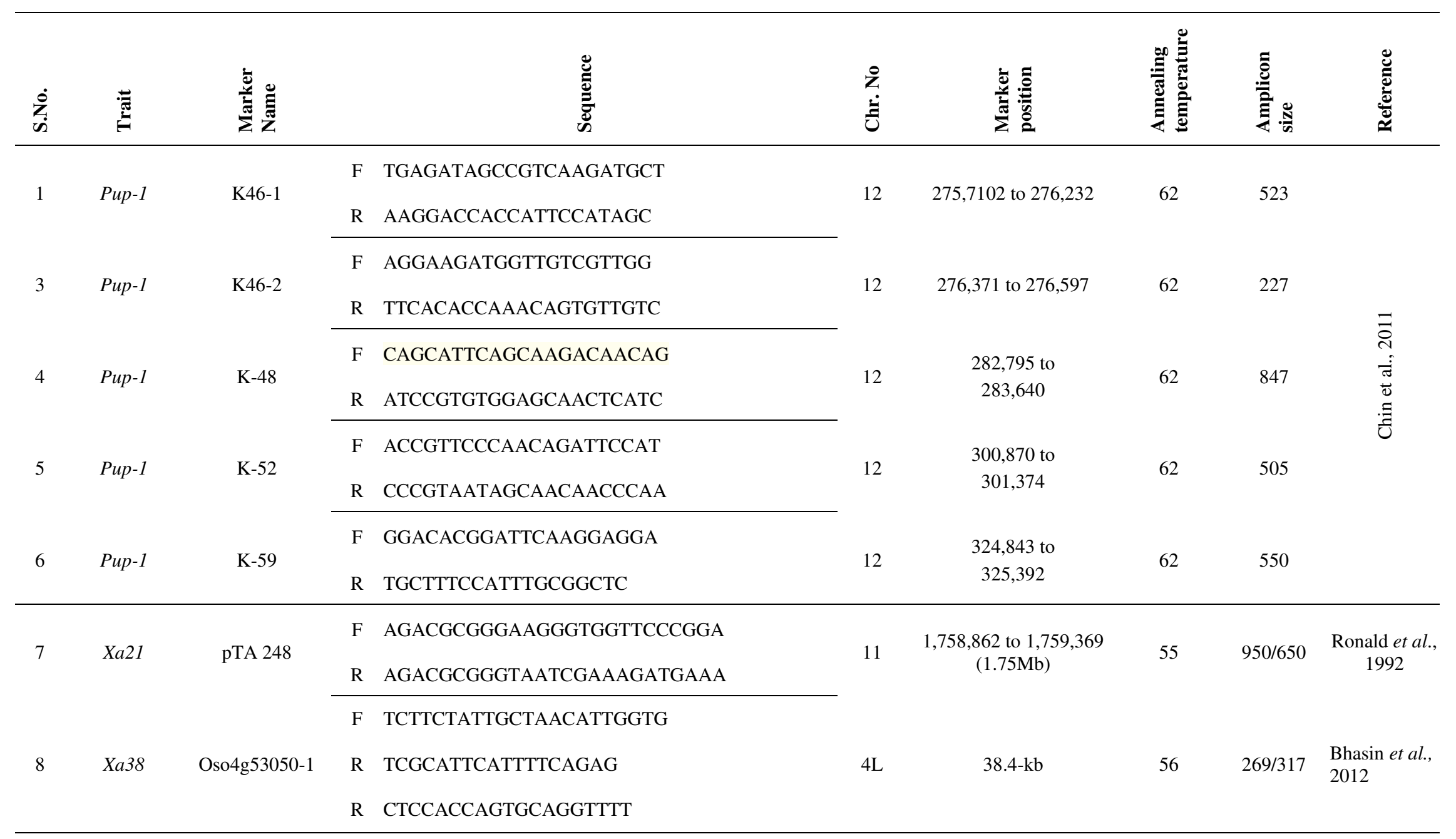


525 Table 2: Evaluation of $\mathrm{ICF}_{3}$ lines (positive for Pup-1, Xa-21 and Xa-38 genes) in Normal soil P plot at ICAR-IIRR, during, Kharif -2018.

526

\begin{tabular}{|c|c|c|c|c|c|c|c|c|c|c|}
\hline Genotypes & $\begin{array}{c}\text { Days to } \\
\mathbf{5 0 \%} \\
\text { Flowering }\end{array}$ & $\begin{array}{l}\text { Plant Height } \\
\quad \text { (cm) }\end{array}$ & $\begin{array}{c}\text { Panicle } \\
\text { Length }(\mathrm{cm})\end{array}$ & $\begin{array}{c}\text { Total } \\
\text { tillers per } \\
\text { plant }\end{array}$ & $\begin{array}{c}\text { Productive } \\
\text { tillers per } \\
\text { plant }\end{array}$ & $\begin{array}{c}\text { Spikelet } \\
\text { Fertility } \\
(\%)\end{array}$ & $\begin{array}{l}\text { 1000 Seed } \\
\text { Weight } \\
\text { (g) }\end{array}$ & $\begin{array}{c}\text { Yield per } \\
\text { Plant } \\
\text { (g) }\end{array}$ & $\begin{array}{l}\text { Root length } \\
\text { (cm) }\end{array}$ & $\begin{array}{c}\begin{array}{c}\text { Root } \\
\text { volume }\end{array} \\
(\mathrm{ml})\end{array}$ \\
\hline BP-10-1 & 84.33 & 73.67 & 21.67 & 12.67 & 12.17 & 80.34 & 19.11 & 20.75 & 16.50 & 26.00 \\
\hline BP-10-3 & 92.00 & 67.67 & 20.83 & 15.67 & 14.67 & 81.36 & 19.00 & 19.65 & 22.67 & 29.33 \\
\hline BP-10-5 & 94.67 & 74.00 & 21.50 & 12.67 & 12.17 & 77.30 & 19.22 & 20.77 & 19.00 & 20.33 \\
\hline BP-10-15 & 91.33 & 72.33 & 21.17 & 12.33 & 12.02 & 83.34 & 19.62 & 21.24 & 19.00 & 22.67 \\
\hline APMS6B & 98.00 & 69.33 & 20.33 & 11.66 & 11.33 & 73.33 & 16.18 & 17.48 & 13.67 & 16.33 \\
\hline $\begin{array}{l}\text { APMS6B NIL } \\
\text { (GU2) }\end{array}$ & 96.00 & 71.00 & 19.55 & 12.33 & 12.00 & 76.52 & 16.94 & 18.33 & 16.00 & 20.00 \\
\hline Kasalath & 86.67 & 98.33 & 21.50 & 12.00 & 10.67 & 79.50 & 18.88 & 15.29 & 22.00 & 17.33 \\
\hline Swarna & 111.00 & 80.93 & 21.00 & 11.00 & 9.33 & 85.04 & 21.85 & 18.74 & 14.00 & 18.00 \\
\hline IR-64 & 91.00 & 82.88 & 17.08 & 9.67 & 8.67 & 83.94 & 21.77 & 18.59 & 21.33 & 27.33 \\
\hline CV & 2.06 & 2.00 & 5.78 & 7.22 & 7.27 & 4.49 & 6.47 & 10.25 & 10.63 & 10.79 \\
\hline CD @ 5\% & 3.24 & 2.57 & 1.99 & 1.48 & 1.4 & 6.04 & 2.08 & 3.26 & 3.26 & 3.97 \\
\hline
\end{tabular}


530 Table 3. Evaluation of $\mathrm{ICF}_{3}$ lines (positive for $\boldsymbol{P u p}-\mathbf{1}, \boldsymbol{X} \boldsymbol{a}-\mathbf{2 1}$ and $\boldsymbol{X a - 3 8}$ genes) in low soil P plot at ICAR-IIRR during Kharif-2018

531

\begin{tabular}{|c|c|c|c|c|c|c|c|c|c|c|}
\hline Genotypes & $\begin{array}{l}\text { Days to } \\
50 \% \\
\text { Flowering } \\
\end{array}$ & $\begin{array}{l}\text { Plant Height } \\
\text { (cm) }\end{array}$ & $\begin{array}{l}\text { Panicle } \\
\text { Length (cm) }\end{array}$ & 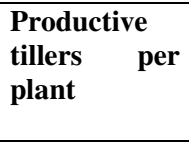 & $\begin{array}{l}\text { Total tillers } \\
\text { per plant }\end{array}$ & $\begin{array}{l}\text { Spikelet } \\
\text { Fertility (\%) }\end{array}$ & $\begin{array}{l}1000 \quad \text { Seed } \\
\text { Weight }(\mathrm{g})\end{array}$ & $\begin{array}{l}\text { Yield } \\
\text { Plant } \\
\text { (g) }\end{array}$ & $\begin{array}{l}\text { Root } \\
\text { length (cm) }\end{array}$ & $\begin{array}{l}\text { Root } \\
\text { volume } \\
\text { (ml) }\end{array}$ \\
\hline BP-10-1 & 96.33 & 64.00 & 17.50 & 9.00 & 9.33 & 75.33 & 15.22 & 10.32 & 24.50 & 32.50 \\
\hline BP-10-3 & 98.33 & 64.00 & 17.75 & 11.50 & 11.50 & 63.38 & 15.20 & 8.61 & 19.50 & 15.00 \\
\hline BP-10-5 & 98.00 & 65.50 & 22.00 & 6.50 & 7.00 & 69.16 & 16.03 & 9.00 & 15.75 & 19.50 \\
\hline BP-10-15 & 99.00 & 68.25 & 18.50 & 6.00 & 8.00 & 71.27 & 14.45 & 11.90 & 17.00 & 25.00 \\
\hline APMS6B & 105.00 & 61.67 & 17.33 & 5.67 & 6.00 & 58.30 & 12.77 & 4.90 & 7.67 & 8.33 \\
\hline $\begin{array}{c}\text { APMS6B NIL } \\
\text { (GU2) }\end{array}$ & 103.00 & 64.33 & 16.25 & 6.00 & 7.00 & 62.20 & 13.79 & 5.80 & 21.83 & 21.67 \\
\hline Kasalath & 98.00 & 86.22 & 16.33 & 9.44 & 9.56 & 69.40 & 17.01 & 8.07 & 20.08 & 17.67 \\
\hline Swarna & 117.33 & 64.67 & 17.17 & 6.33 & 8.67 & 77.04 & 17.53 & 8.05 & 11.67 & 16.33 \\
\hline IR-64 & 111.08 & 51.00 & 13.00 & 4.00 & 4.67 & 72.18 & 17.33 & 5.01 & 19.00 & 23.33 \\
\hline CV & 2.76 & 3.74 & 6.23 & 14.19 & 15.21 & 6.67 & 9.18 & 10.63 & 7.01 & 24.16 \\
\hline CD @ 5\% & 4.77 & 4.11 & 1.81 & 1.71 & 2.03 & 7.69 & 2.38 & 1.42 & 2.05 & 8.08 \\
\hline
\end{tabular}

532

533 
Table 4: Stress indices calculated for Pup-1 introgressed APMS-6B ICF 3 lines based on per plant yield under normal and Low soil P conditions.

\begin{tabular}{lllllll}
\hline $\begin{array}{l}\text { Genoty } \\
\text { pe }\end{array}$ & $\begin{array}{l}\text { NORMAL } \\
\text { P }\end{array}$ & $\begin{array}{l}\text { P STRESS/ } \\
\text { LOW P }\end{array}$ & $\begin{array}{l}\text { STI/ stress tolerance } \\
\text { index }\end{array}$ & $\begin{array}{l}\text { SSI/ stress susceptibility } \\
\text { index }\end{array}$ & $\begin{array}{l}\text { YSI/ yield stability } \\
\text { index }\end{array}$ & $\begin{array}{l}\text { \% Yield } \\
\text { reduction }\end{array}$ \\
\hline BP-10-1 & 20.75 & 10.32 & 0.59 & 0.87 & 0.50 & 50.26 \\
BP-10-3 & 19.65 & 8.61 & 0.47 & 0.97 & 0.44 & 56.17 \\
BP-10-5 & 20.77 & 9.00 & 0.52 & 0.98 & 0.43 & 56.65 \\
BP-10- & 21.24 & 11.90 & 0.70 & 0.76 & 0.56 & 43.99 \\
15 & & & & & & \\
APMS6 & 17.48 & 4.90 & 0.24 & 1.24 & 0.28 & 71.97 \\
B & 18.33 & 5.80 & 0.29 & 1.18 & 0.32 & 68.38 \\
GU-2 & & 0.34 & 0.81 & 0.53 & 47.23 \\
Kasalat & 15.29 & 8.07 & 0.42 & 0.98 & 0.43 & 57.05 \\
h & & 8.05 & 0.26 & 1.26 & 0.27 & 73.05 \\
Swarna & 18.74 & 5.01 & & & \\
IR-64 & 18.59 & & &
\end{tabular}

537 